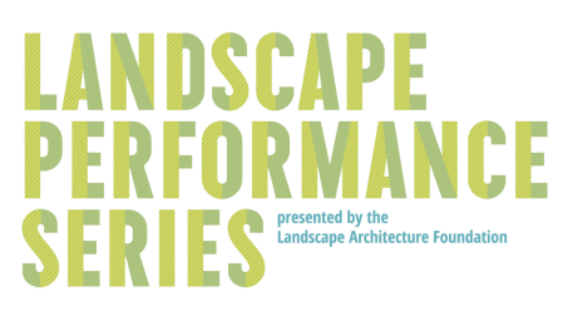

\title{
Evelyn Pease Tyner Interpretive Center and Kent Fuller Air Station Prairie Methods Document
}

Prepared by

Research Fellow: M. Elen Deming, Professor, University of llinois, Urbana-Champaign Research Assistant: D. Scott Douglas, MLA Candidate, University of Illinois, UrbanaChampaign

Firm Liaison: Danielle Fisher, Marketing Coordinator, Conservation Design Forum, Elmhurst , IL

Overview of CSI: This investigation was conducted as part of the Landscape Architecture Foundation's 2015 Case Study Investigation (CSI) program. CSI matches faculty-student research teams with design practitioners to document the benefits of exemplary high-performing landscape projects. Teams develop methods to quantify environmental, economic and social benefits and produce Case Study Briefs for LAF's Landscape Performance Series.

The full case study can be found at: https://landscapeperformance.org/case-studybriefs/tyner-interpretive-center 


\section{Landscape Performance Benefits}

\section{Environmental:}

\section{Retains $100 \%$ of on-site stormwater runoff for more than a 100 -year, 24 -hour}

storm event.

The construction of the interpretive center and its associated pathways resulted in an increase of 8,873 square feet in impervious area over the 32-acre site. However, this increase is offset by the use of pervious paving for pathways, the minimization of on-site parking, and the green roof on top of the building, which results in a net increase of $0.64 \%$ in impervious area over the entire site.

The Evelyn Pease Tyner Interpretive Center is located in a shallow depression, entirely surrounded by a ridge that does not allow surface water to run off the site. Depressed wetland areas on the site thus collect and retain all stormwater that falls on the site; there are no stormwater outfalls for the lowest areas of the wetlands.

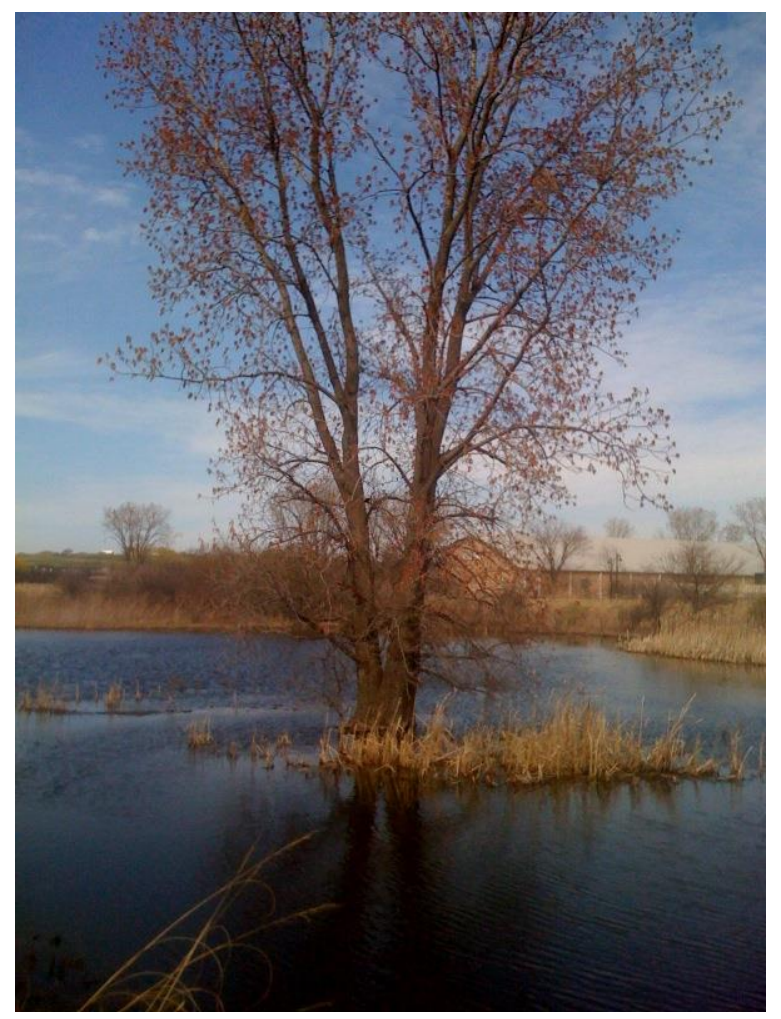

Spring storage of on-site stormwater at Evelyn Pease Tyner Interpretive Center. 
Landscape Architecture Foundation (M.E. Deming, CSI 2015)

Design storm:

The project engineer's calculations submitted with the LEED application utilized the rational method and a 1.5-year, 24-hour storm that generates 2.78 " of rainfall.

Baseline condition:

2.78 " $X 0.08333$ (convert in to ft) $X 43,560$ (sf in an acre) $X 32$ acres $X 0.20$ (site runoff coefficient, calculated by the engineer) $=$

$64,584.96$ cu ft $X 1 / 43,560=1.48$ acre $\mathrm{ft}$ in required storage for the baseline condition.

Design condition:

2.78 " $\times 0.08333 \times 43,560$ (sf in an acre) $\times 32$ acres $\times 0.206$ (design runoff coefficient, calculated by the engineer, shows a minimal increase over baseline) $=$

66,522.51 cu ft $X 1 / 43,560=1.53$ acre $\mathrm{ft}$ in required storage for the design condition.

Wetland volume:

The depressed wetland areas provide 1,242,357.34 cu ft of storage volume (28.52 acre $\mathrm{ft})$. The 1.53 acre $\mathrm{ft}$ of required storage is readily contained within the 28.52 acre $\mathrm{ft}$ provided storage and the lack of an outfall results in a discharge of $\mathbf{0 . 0}$ cfs runoff from the site.

The CSI team also ran these calculations using the current 100 -year storm rate of 7.584" in 24 hours:

7.584 " X $0.08333 \times 43,560$ (sf in an acre) X 32 acres X 0.206 (design runoff coefficient, calculated by the engineer) $=$

$181,469.97$ cu ft $\times 1 / 43,560=4.17$ acre $\mathrm{ft}$ in required storage for the design condition, which is also easily contained within the 28.52 acre $\mathrm{ft}$ provided on site. 


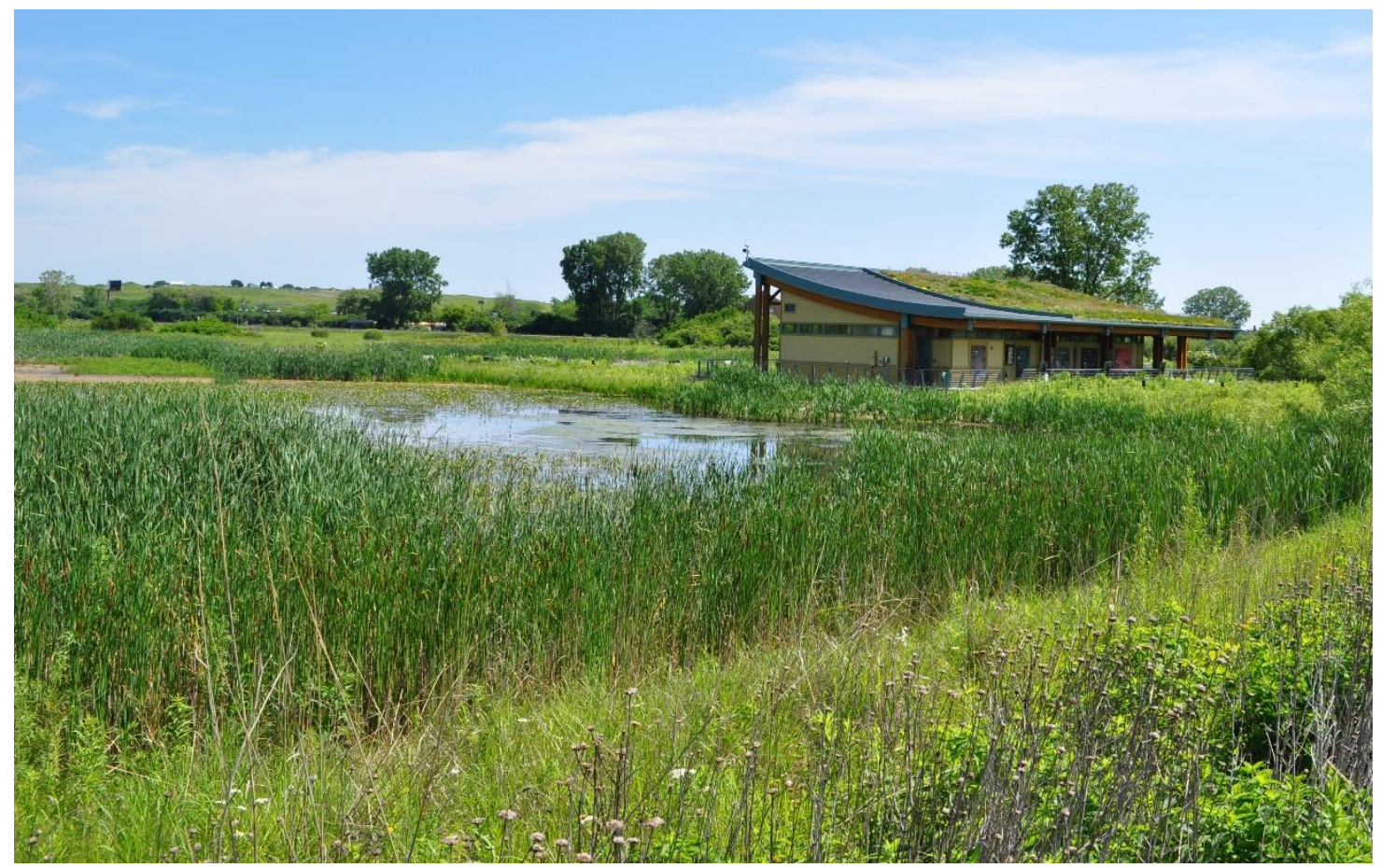

Wetlands provide on-site storage of all stormwater runoff and a unique educational landscape due to their ephemeral nature. Landscape Architecture Foundation (Scott Douglas, CSI2015)

Source:

- Evelyn Pease Tyner Interpretive Center LEED Application for Certification v2.1 dated December 2006

2. Increased ecological quality as demonstrated by an increase in Floristic Quality Index (FQI) from 44.7 in 1996 to 62.8 in 2014. An FQI above 35 is considered to be "natural area" quality.

The prairie, previously a strip of land adjacent to the former naval air station runway, quietly subsisted until the federal government decided to close the air station in 1995. Although considered to be in a degraded state, the site was identified as a plot of land that was worth conserving and restoring. Below is a summary of studies that have been done on this area.

The Floristic Quality Index (FQI) is a measurement of quality of a landscape area Methodology Page $\mathbf{4}$ of $\mathbf{2 3}$ 
based on the specific plants that are found on the site. Each plant is given a rating based on its adaptability. Plants that can only grow in a specific environment are given high ratings while those that thrive over a wide range of conditions are given a lower rating. FQI ratings are evaluated by the following ranges:

1-19 Low vegetative quality

20-35 High vegetative quality

$35+\quad$ "Natural area" quality

\section{Method}

Harza Environmental Services studied the site in August 1995 with the following results for species counts and Floristic Quality Index (FQl):

Waste Ground Area:

23 Native species

66 Total species

1.22 Native mean $\mathrm{C}$

$0.42 \mathrm{~W} /$ adventives

5.84 Native FQI

3.45 W/adventives
Prairie Area:

137 Native species

179 Total species

4.09 Native mean C

$3.13 \mathrm{~W}$ /adventives

47.84 Native FQI

$41.86 \mathrm{~W} /$ adventives

(Note that adventive species are plant species that have arrived in a specific geographic area from a different region.)

The prairie area was reevaluated in October 1996 by Conservation Design Forum (K. Johnson \& G. Wilhelm) with the following results:

149 Native species

191 Total species

4.15 Native mean C

3.24 W/adventives

50.63 Native FQI

44.72 W/Adventives

An inventory of plant species dated June 2012 was provided by Kent Fuller, a 
volunteer with the North Branch Restoration Project and the namesake of the prairie. That list identified 253 plant species in the prairie area. Of the 62 species added since the 1996 study, only 5 were identified as adventive species. Unfortunately, FQI calculations were not included with the list.

206 Native species

253 Total species

n/a Native mean C

n/a W/adventives

n/a Native FQI

n/a W/Adventives

It should be noted that the 2012 list encompasses the entire 32-acre site and is not focused on the 14-acre site that Harza identified as prairie. However, Harza did state that "given the intermingling of the old-field and prairie parcels in and around the periphery, the overall size of the area containing prairie parcels is 20 to 30 acres."

An inventory of the prairie, entitled KF Air Station Prairie, was posted on the website universalfqa.org on $1 / 21 / 2014$. The inventory was compiled on the website by Gayle Laboda. As with the 2012 study, this list encompasses the entire 32-acre site. 217 Native species

273 Total species

4.8 Native mean $\mathrm{C}$

3.8 W/adventives

70.7 Native FQI

62.8 W/Adventives

Considered as a timeline, these results show a steady increase in native plant species and overall FQl; however, adventive species are continuing to increase as well. The North Branch Restoration Project actively collects, sorts, and redistributes native plant seeds from this site and 13 other sites for which they provide stewardship. While the CSI team cannot credit the FQI increase entirely to their efforts, it is probable that 
their work is having a positive effect on Floristic Quality. The increase in adventive species, despite the continued effort to eradicate them from the site, is concerning, however, the quantity and distribution of these species is unknown.

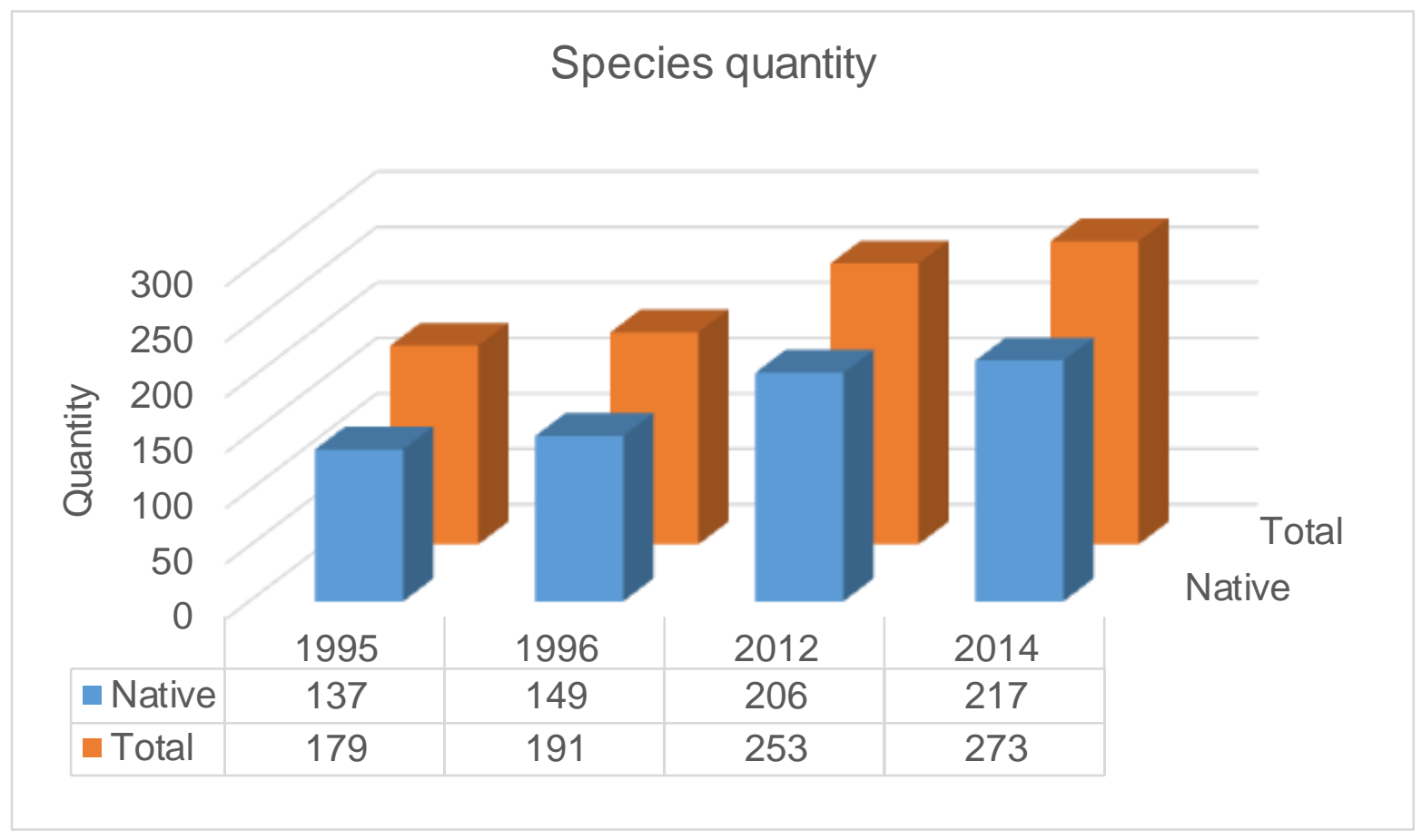

1995 native species: 137

2014 native species: 217

$217-137=80$ additional native plant species at the site $80 / 137=0.584=58.4 \%$ increase in the quantity of native species

Sources:

- Conservation Design Forum, Inc., 1997. A Report on the Prairie Community at the Former Glenview Naval Air Station Including a Delineation and Habitat Assessment, a Management Plan, and Examples of Natural Areas Preservations/Restorations within Corporate Settings. Conservation Design Forum, Inc., Naperville, IL.

- Laboda, Gayle, 2014. KF Air Station Prairie Plant Inventory, Glenview, IL. http://universalfqa.org/view_public_inventory/282

- Harza Environmental Services, 1995. Glenview Naval Air Station Ecological Study of Upland Vegetative Types. Harza Engineering, Chicago, IL. 
http://www.fws.gov/midwest/endangered/section7/s7process/plants/FQA.html

\section{Generates $16,649 \mathrm{kWh}$ of solar power annually, or $53.7 \%$ of the building's energy use. This saves $\$ 975$ in energy costs each year.}

The Tyner Interpretive Center building was intended to have a net zero energy consumption. The building's power consumption was minimized through the use of polyurethane heat-saving insulation, a 6 -in- thick green roof, and a geothermal energy system. One sixth of the building roof is covered in photovoltaic roof shingles that were anticipated to generate enough energy to offset the building's power consumption.

Based on power consumption numbers for the year 2010 (the only year of data provided), the Center's energy efficiency has fallen victim to its popularity. The building's architect informed the CSI team that the building is being used much more than was intended during the design phase. This additional usage has resulted in increased energy consumption. Fortunately, the solar panels are generating enough energy to offset $53.7 \%$ of the building's power consumption. This results in an estimated savings of $\$ 975.63$ at the current rate of 5.86 cents $/ \mathrm{kWh}$.

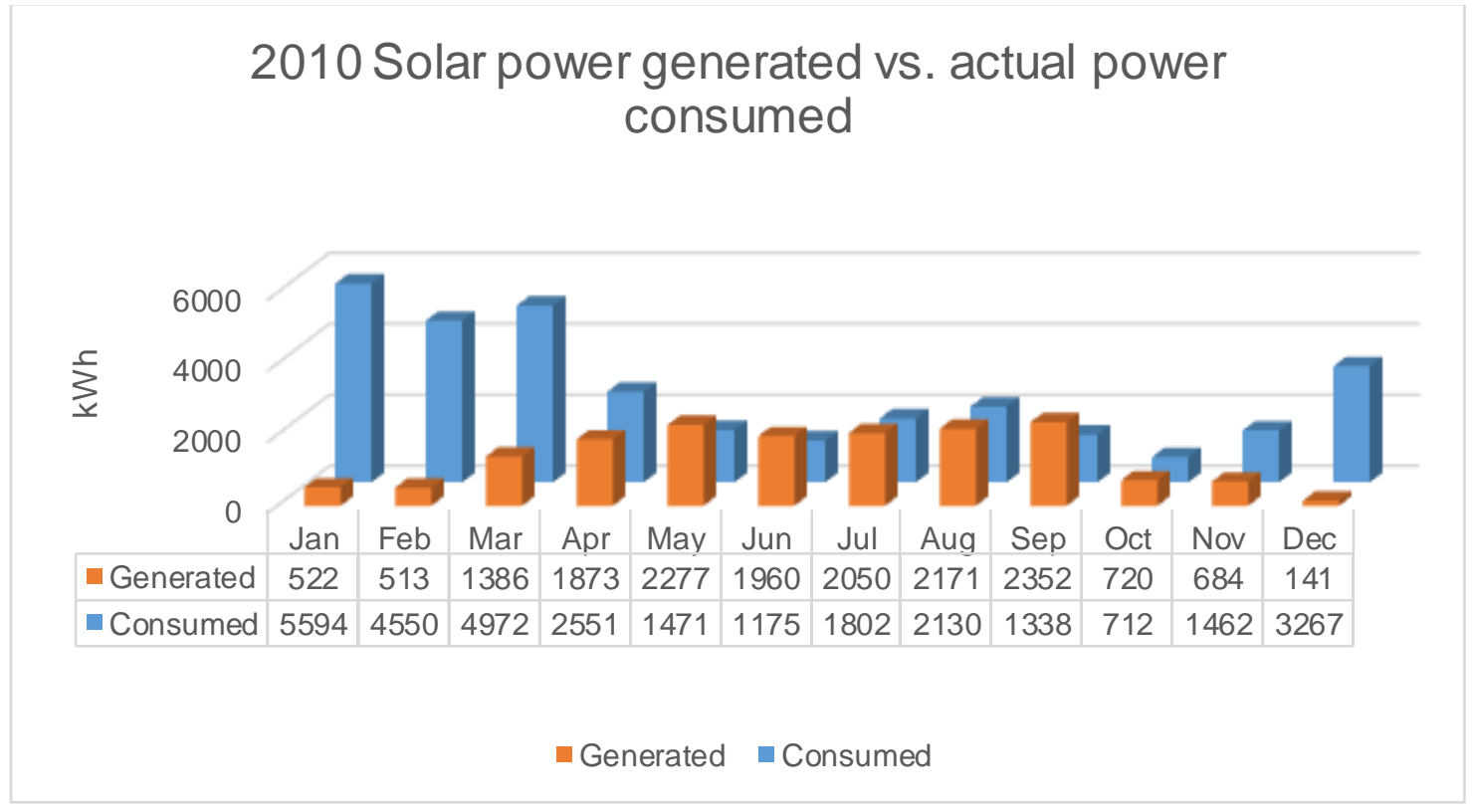


2010 Total power consumed: $31,024 \mathrm{kWh}$

2010 Total power generated: $16,649 \mathrm{kWh}$

$16,649 / 31,024=0.5366=53.7 \%$ of total power consumed is generated by solar power

The CSI team also evaluated the actual power generation versus the estimate that was generated during the design phase and included in the LEED certification application.

For the entire year of 2010 , the solar panels generated only $88.62 \%$ of the total amount $(\mathrm{kWh})$ estimated. The difference between the actual and the estimated amount varied dramatically: compare the solar power system in December-only generating $18.88 \%$ of the estimated amount with what it generated in April-120.92\% of the estimated levels. Local atmospheric conditions appear to have a pronounced effect on the assumed efficiency of the system.

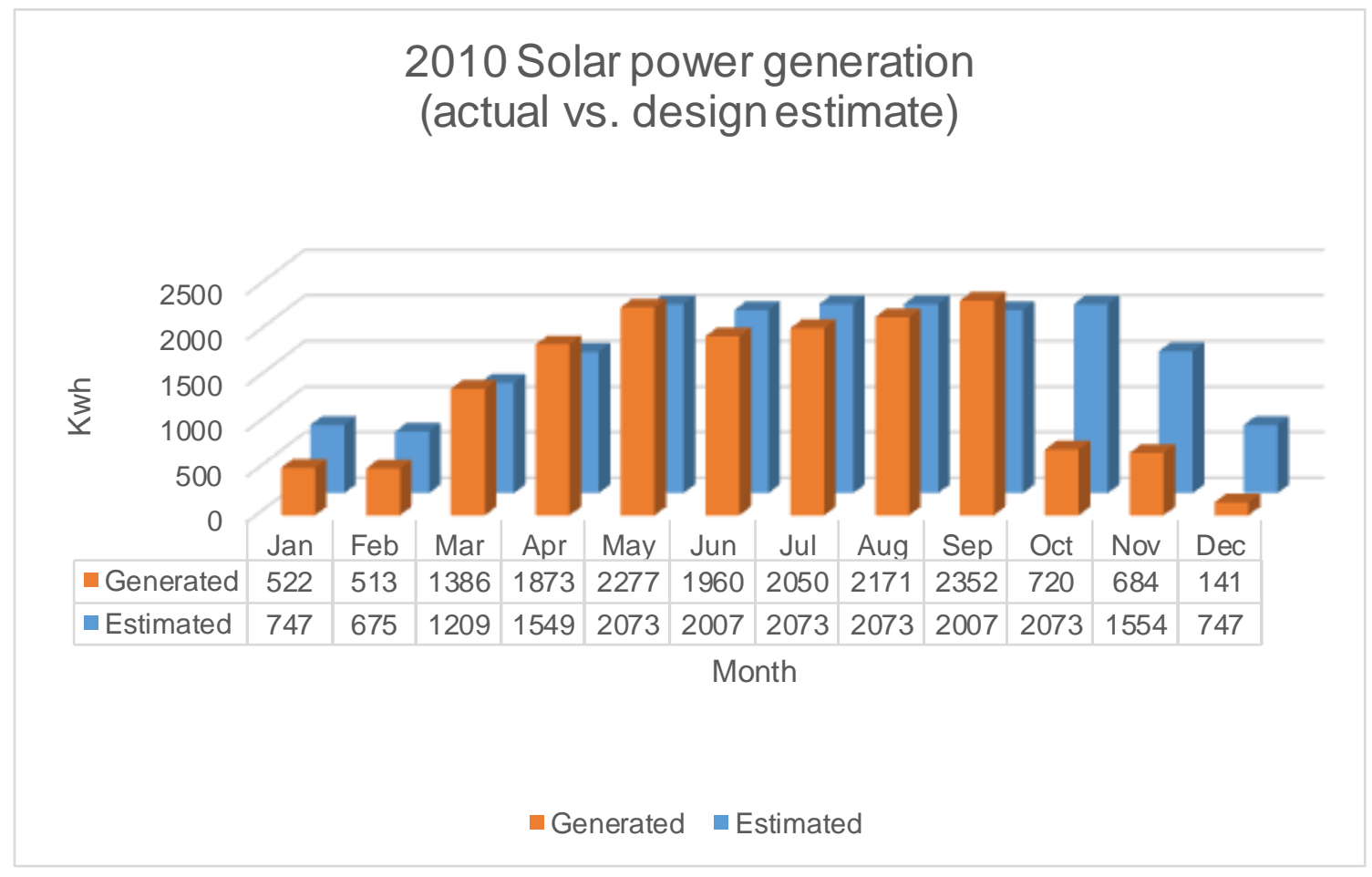

Sources:

- Solar generation and power consumption data provided by the Glenview Park District

- Correspondence with the building architect at Wight and Company 
- Estimated usage data from the Evelyn Pease Tyner Interpretive Center LEED Application for Certification v2.1 dated December 2006

- https://www.comed.com/customer-service/rates-pricing/ratesinformation/Pages/current-rates.aspx

\section{Social}

\section{Hosts year-round classes and special events for an average of 5,664 visitors annually.}

The prairie and exhibits outside of the interpretive center are open every day from sunrise to sunset. However, the interpretive center building is only open on Tuesday, Thursday, and Saturday from 9:00am to 3:00pm or during special events. Because attendance numbers are only recorded by staff for 18 hours per week when the interpretive center is open, these attendance counts do not include all other visitors that visit the site each year when the Center is closed. Attendance data for the 2009-2010 and 2010-2011 periods was not available.

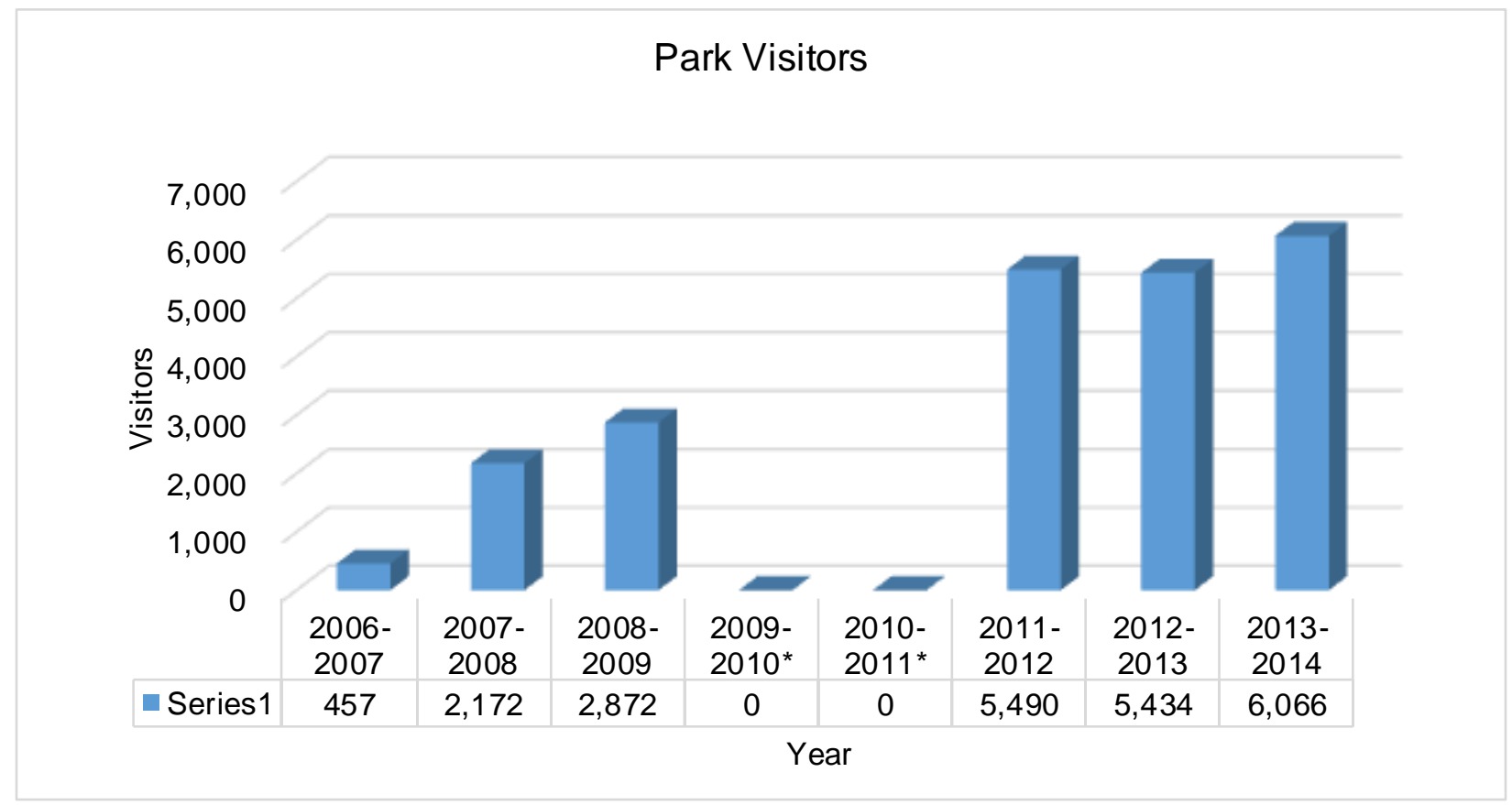

*Data for the 2009-2010 and 2010-2011 periods was not available. 
Average total attendance 2011-2014:

$5,490+5,434+6,066=16,990$ visitors $/ 3$ years $=$ average 5663.333 visitors per year (when the interpretive center is open and counting visitors)

Interior and exterior exhibits include a sample construction of a green roof, a chalkboard listing of recent bird sightings, informational signage about prairie ecology, prairie burns and maintenance, and native plant species. This signage provides opportunities for visitors to learn about, understand, and appreciate the natural beauty and function of the local prairie ecosystem. The signage also educates visitors about the green technologies that are utilized throughout the building.

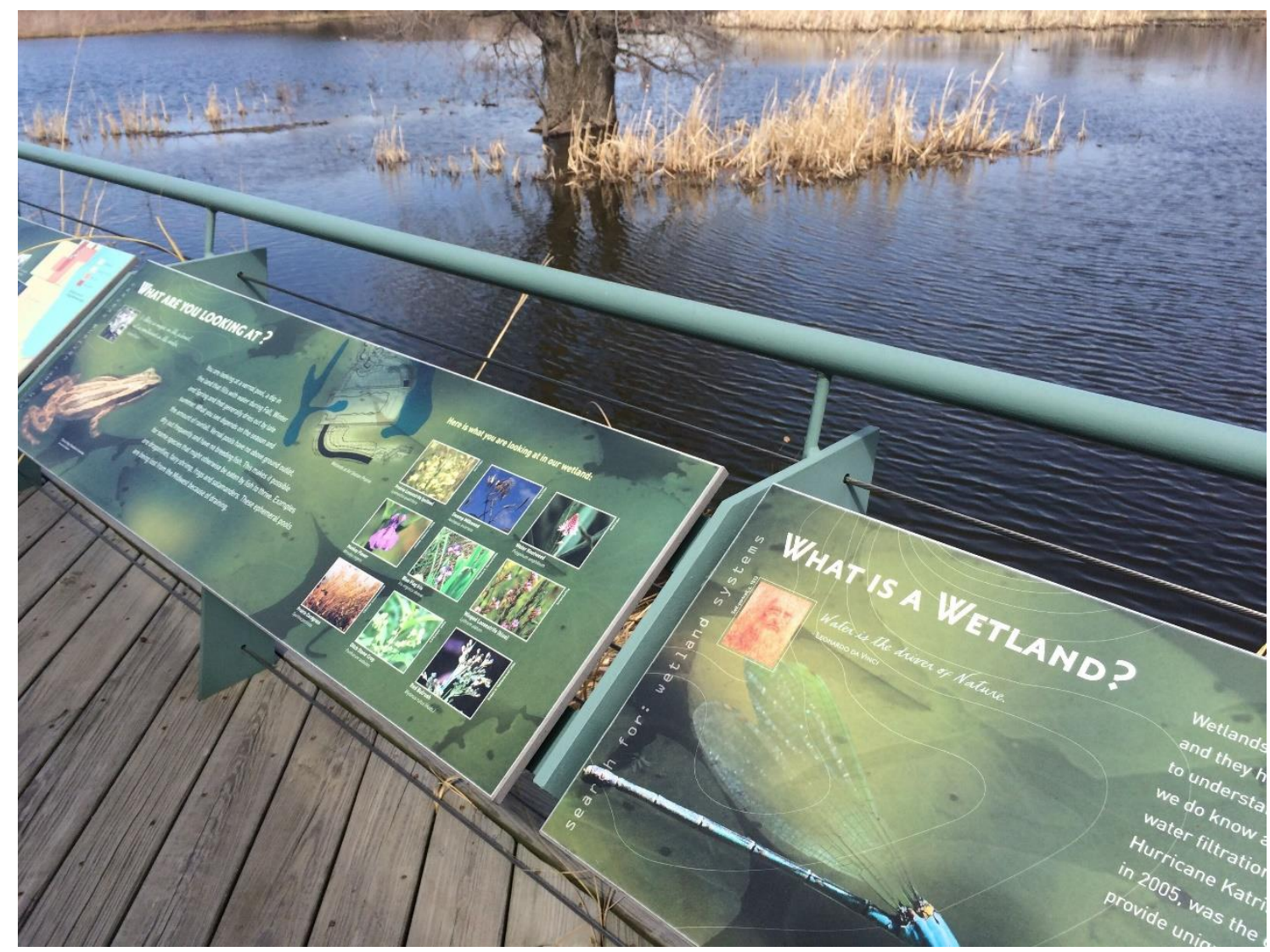

Signage distributed throughout the site provides educational information to visitors of all ages. Photo by Danielle Fisher, Conservation Design Forum. 
Inside the interpretive center, a large common room features views out to the prairie along with a collection of tables and chairs that can be configured for a variety of different tasks and activities. During the winter months, tables and chairs can be moved to the perimeter of the room to make room for the Saturday morning yoga class.

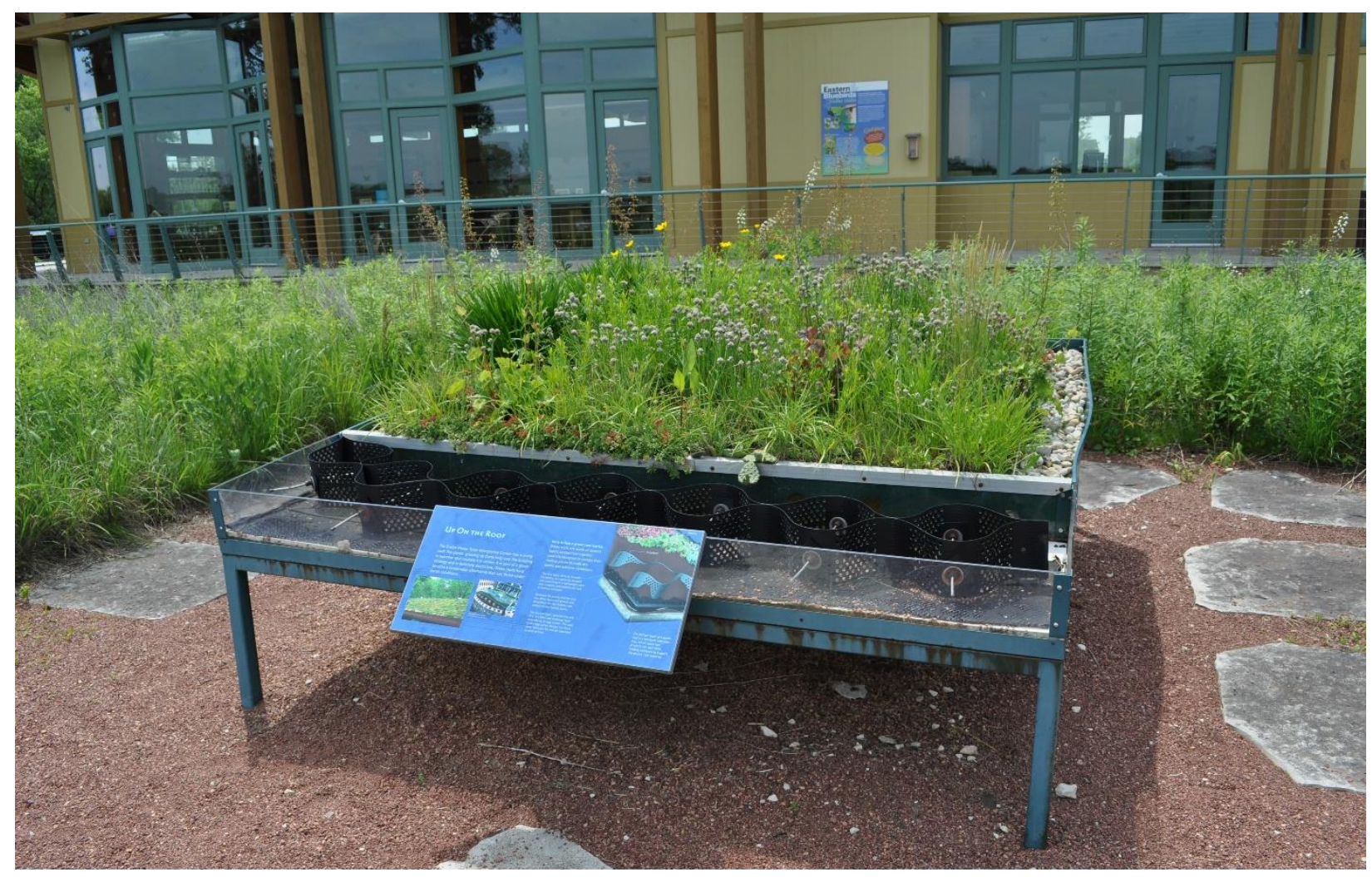

The green roof educational display introduces the general public to the construction of green roof systems and their benefits. Landscape Architecture Foundation (Scott Douglas, CSI 2015)

Source:

- Attendance data provided by the Glenview Park District

2. Provides opportunities for an average of 118 volunteers and generates over 472 volunteer hours annually, with an estimated value of $\$ 11,677$.

In order to maintain and improve the overall quality of the prairie, a combination 
of park district employees, contractors, and volunteers work on the prairie. The volunteer effort for this site is most impressive, as it shows the importance of this site to the residents in the surrounding area. Volunteer workdays are coordinated through the North Branch Restoration Project, a group of citizens that aid in the maintenance of 14 sites along the north branch of the Chicago River, including the Air Station Prairie.

Volunteer workdays typically include time dedicated to weed and invasive species removal (including white sweet clover) and seed collection. As recorded over the past 3 seasons, an average of 118 volunteers per year have worked during restoration workdays; each work session averages 4 hours per volunteer. 118 volunteers $\times 4$ hours $=472$ volunteer hours.

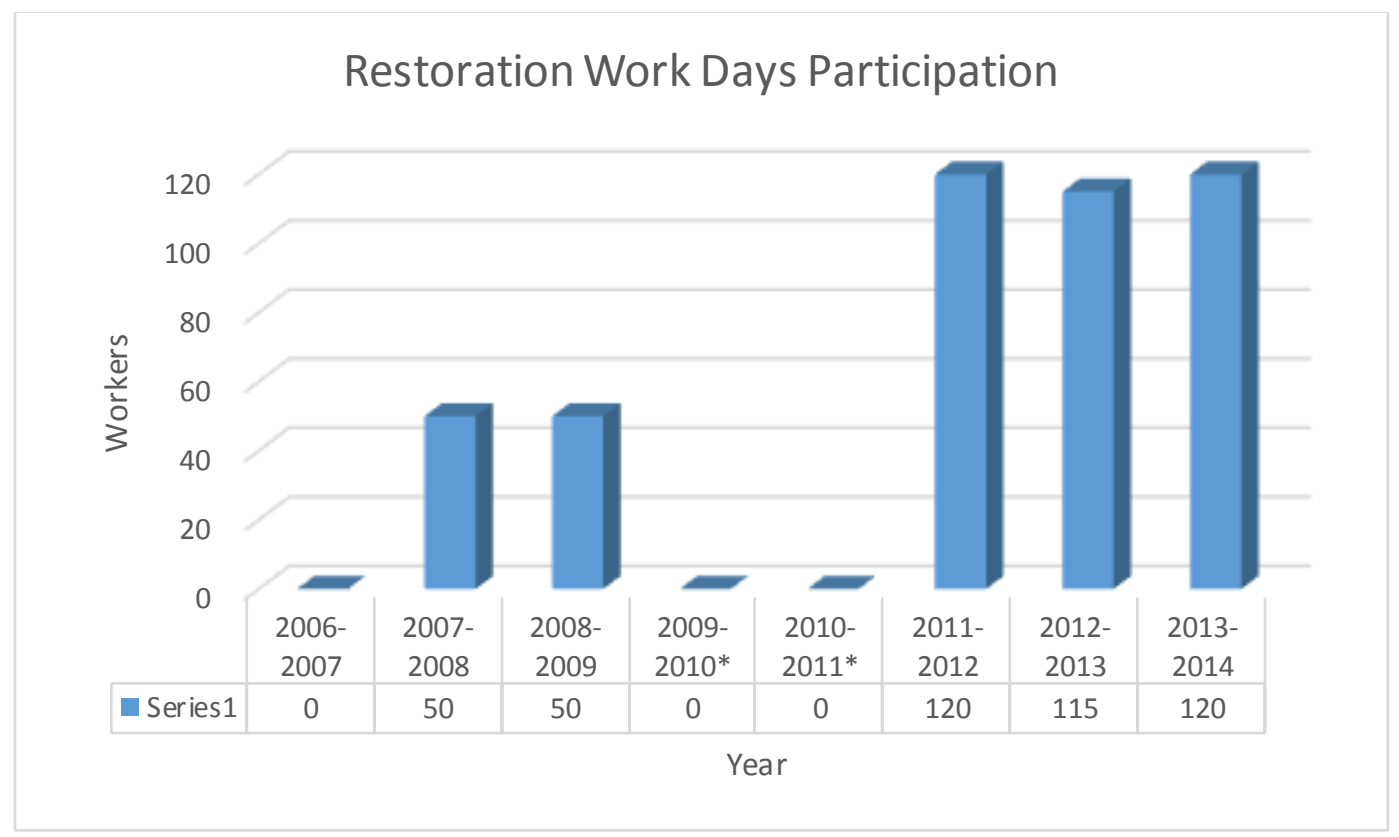

*Data for the 2009-2010 and 2010-2011 periods was not available.

472 hours $\times \$ 24.74$ (Illinois value of volunteer hours suggested by Independent Sector, a leadership network for nonprofits) $=\$ 11,677.28$

In addition to official workdays, some individual volunteers provide additional volunteer hours at the prairie. One such volunteer is Kent Fuller, after whom the prairie is named. Mr. Fuller provides over 100 hours per year-over and above the regularly 
scheduled volunteer workdays-in an effort to control invasive exotic species through selective spraying of herbicides and manual removal. The level of dedication to the ongoing restoration that is shown by these volunteers reveals the importance of this site to the community.

The park district contributes $\$ 1,000$ per year to the North Branch Restoration Project in exchange for their stewardship. Based on a minimum of 572 volunteer hours (work day hours + Mr. Fuller's additional time), that equals a labor rate of $\$ 1.75$ per hour. At the lllinois volunteer rate of $\$ 24.74$, the value of this work is $\$ 14,151.28$.

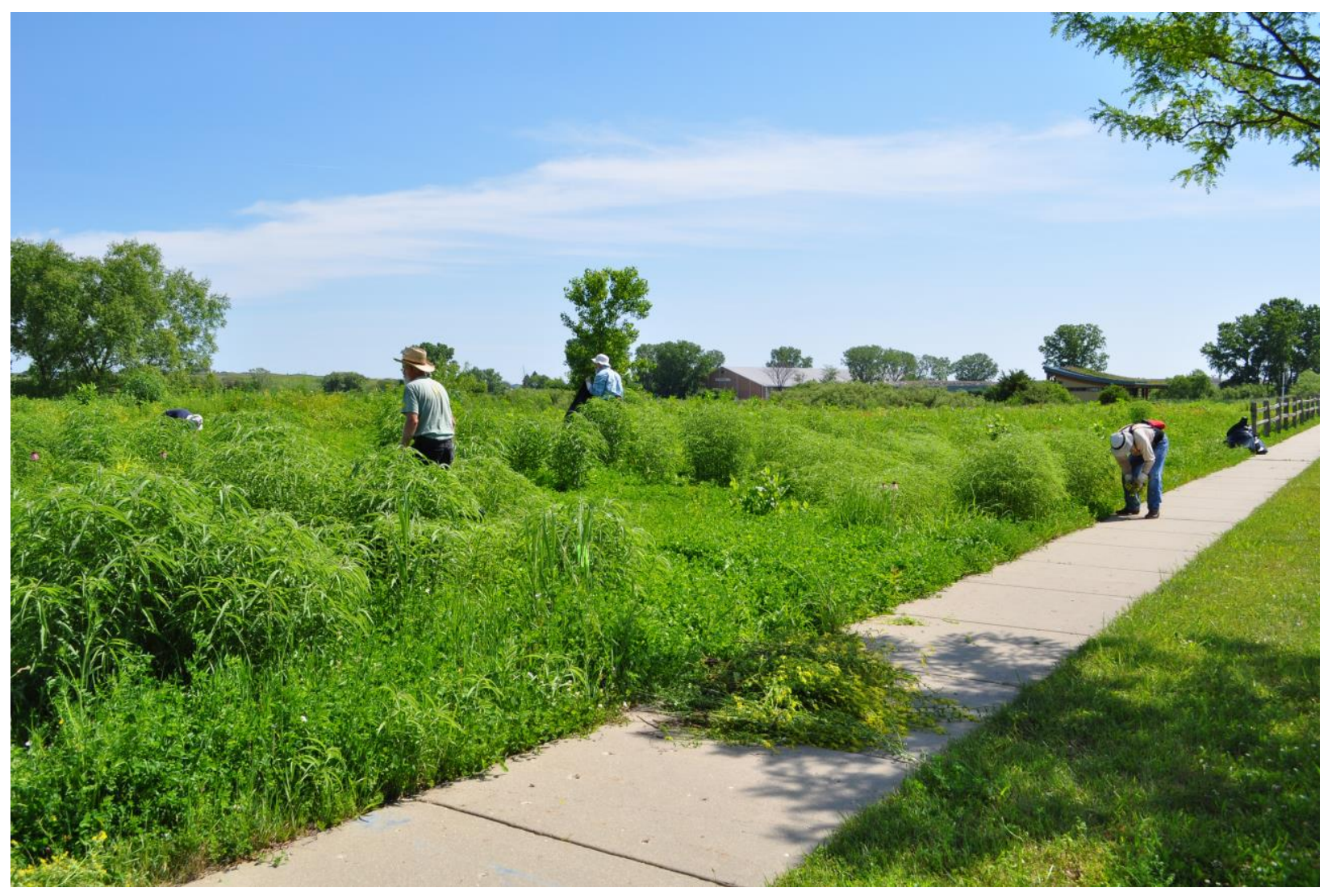

Volunteers work to clear Yellow Sweetclover (Melilotus officinalis) from the outer perimeter of the facility. Landscape Architecture Foundation (Scott Douglas, CSI 2015)

Source:

- Attendance data provided by the Glenview Park District 
- On-site interview of volunteers

- https://www.independentsector.org/volunteer time

\section{Generates average revenues of $\$ 20,737$ annually through classes and building rental fees.}

Despite its small footprint and limited operating hours (the interpretive center building is only open on Tuesday, Thursday, and Saturday from 9:00 am to 3:00pm or during special events), the interpretive center is a significant source of revenue for the park district.

Method

Over the past 3 seasons $(2011-12,2012-13,2013-14)$, the center has generated annual average revenues of $\$ 20,737$.

\section{Revenue generated}

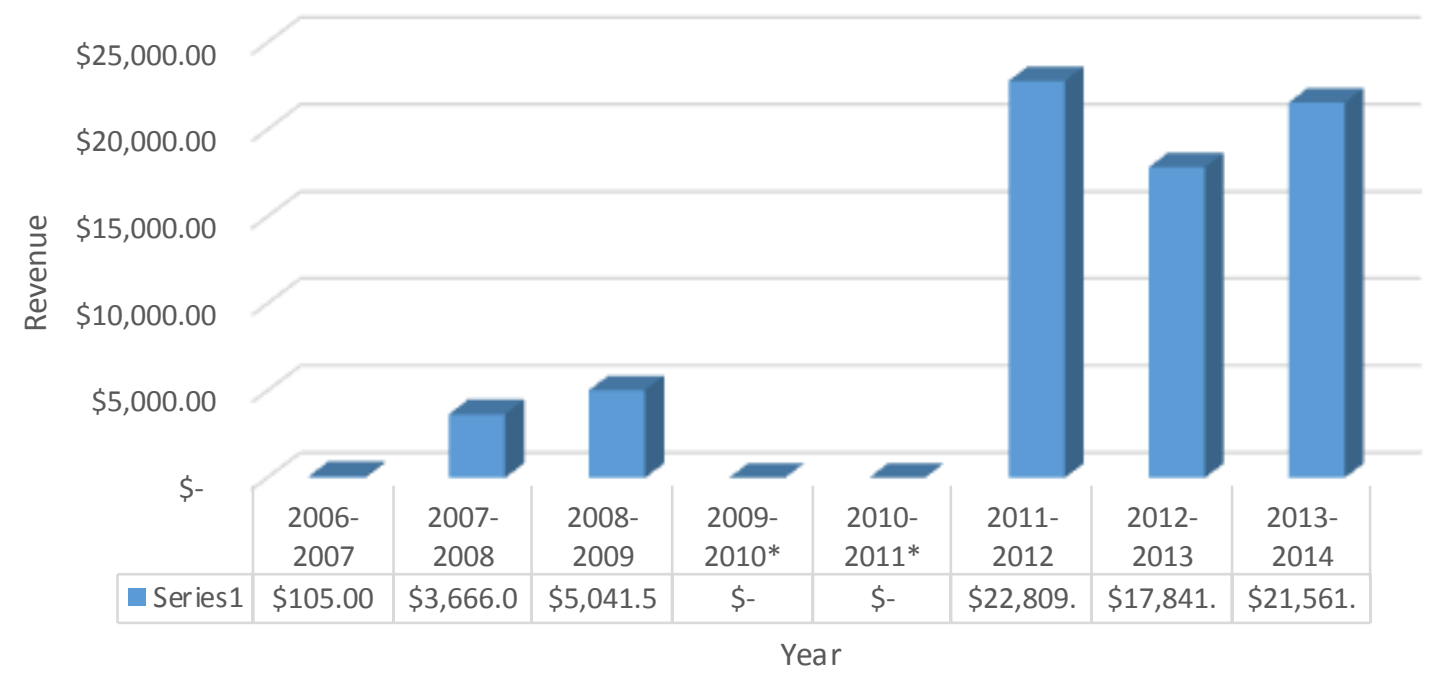

*Data for the 2009-2010 and 2010-2011 periods was not available.

Over the last three seasons, the top two revenue sources for the interpretive center are visits by school groups and the Saturday morning yoga classes. Those two categories generated $91 \%$ of the income that the interpretive center earned in the 201314 season. 


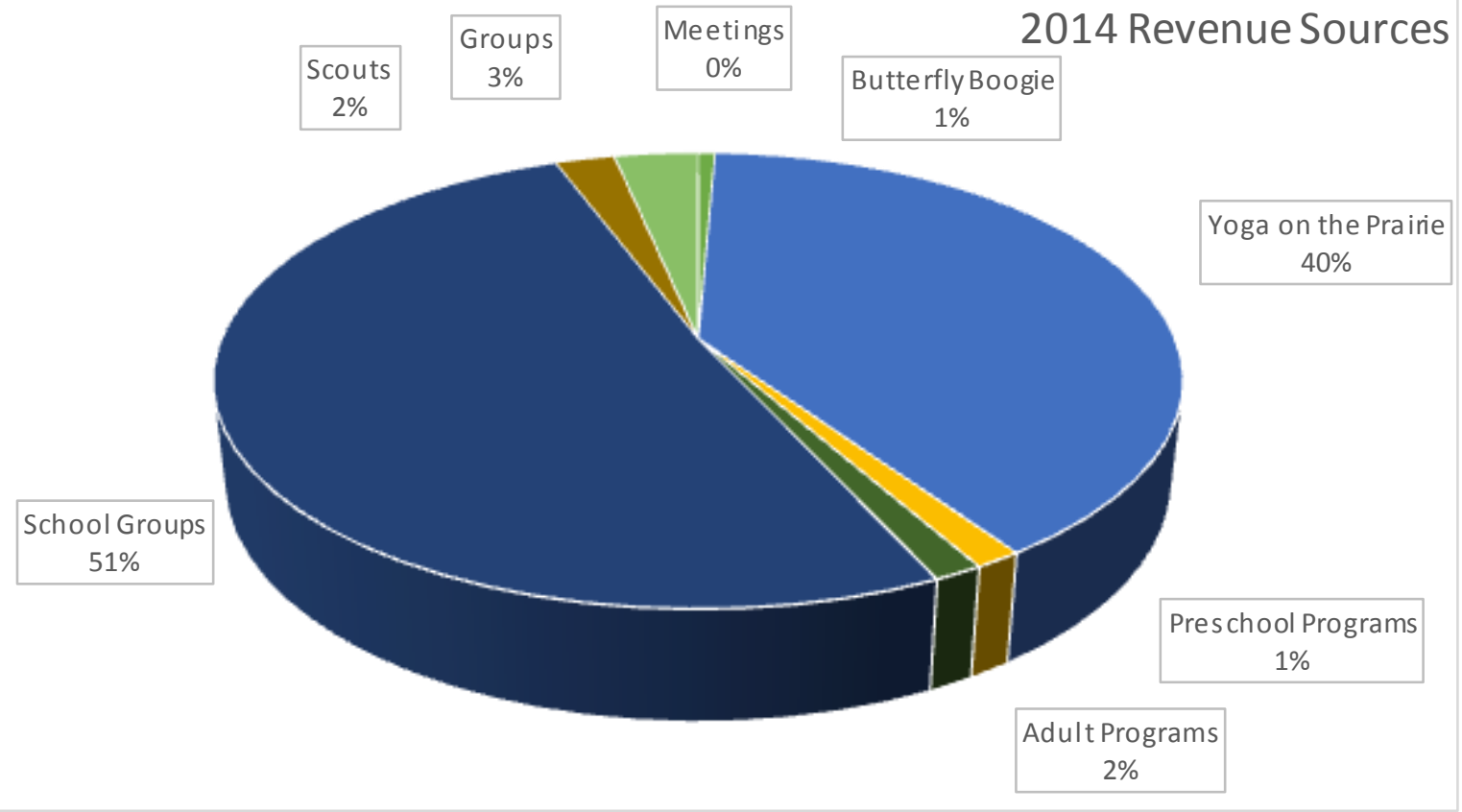

Revenue - School Visits

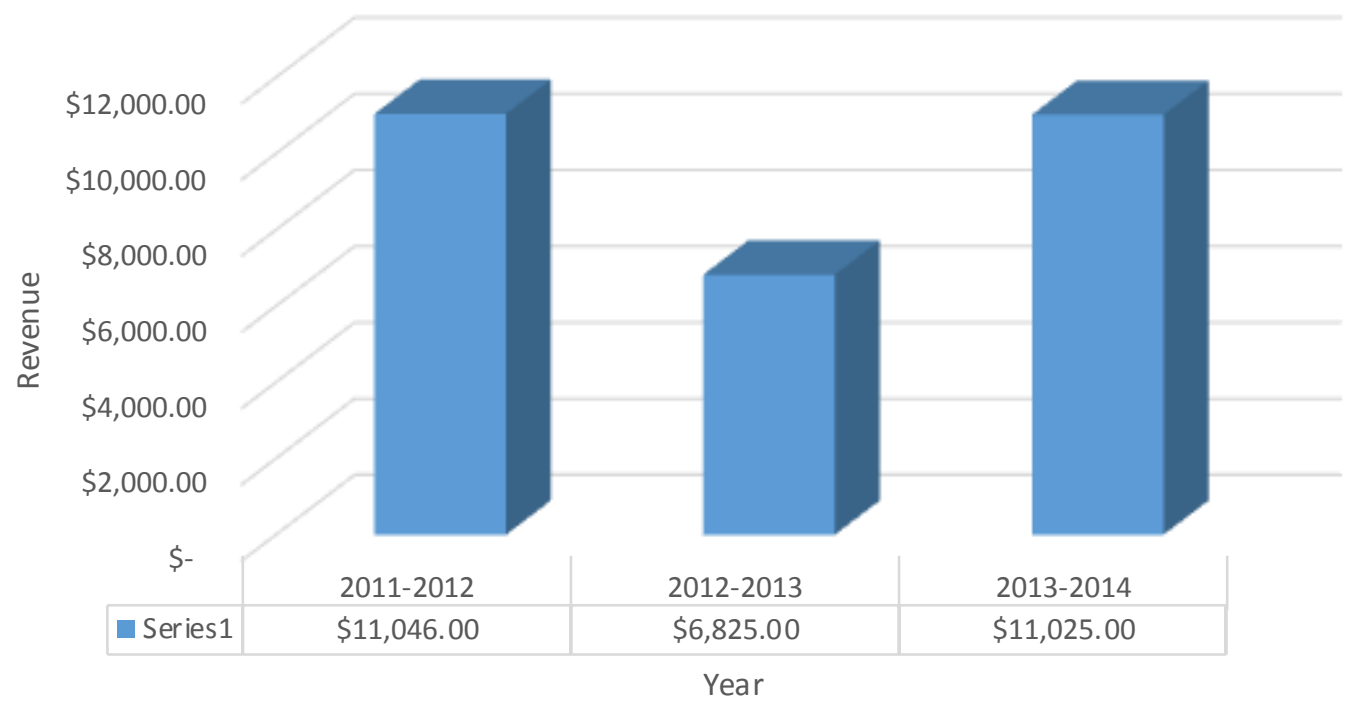




\section{Revenue - Yoga on the Prairie}

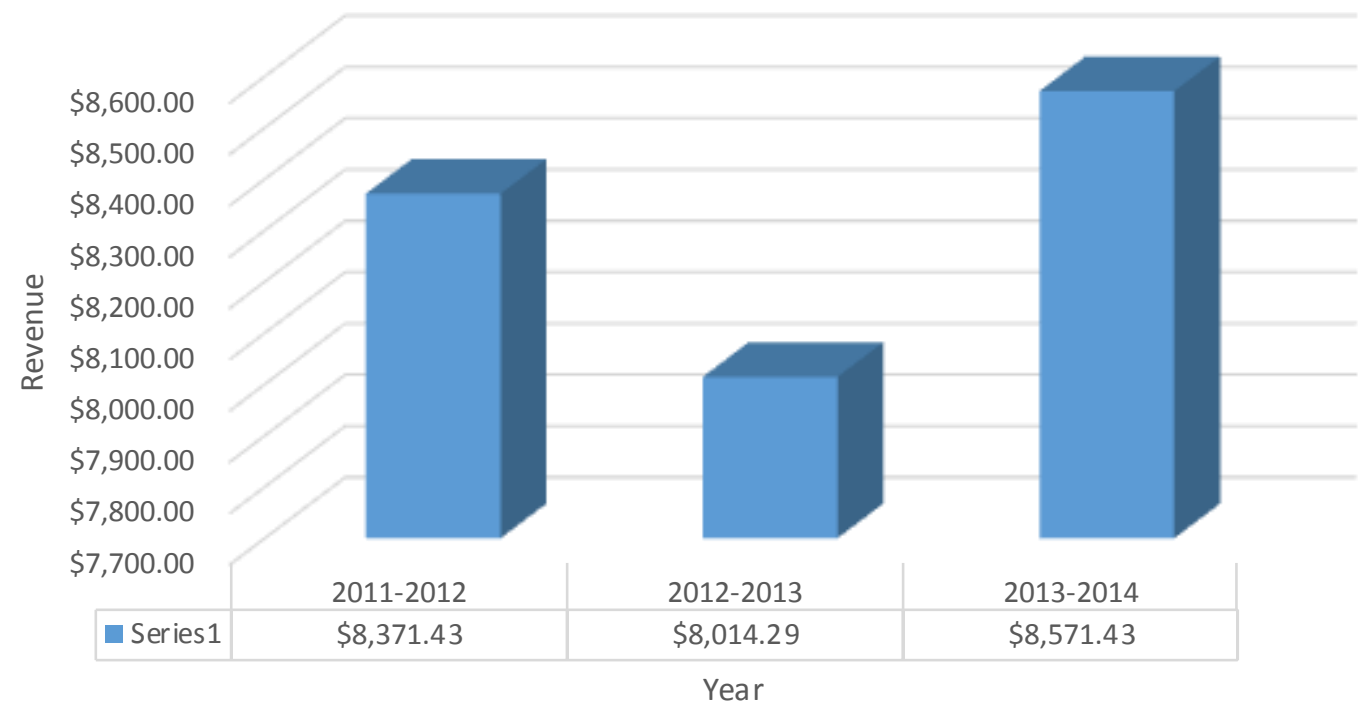

Source:

- Attendance data and class fee information provided by the Glenview Park District

\section{Cost Comparison}

The design team evaluated two options for paving the 2,100-sf parking/pull-off area: one with standard asphalt and one using permeable pavers. The design team calculated that the permeable option was $\$ 5$ per sf more expensive, resulting in a $\$ 10,500$ premium to install permeable pavers instead of asphalt.

The final decision to spend the additional money and install the permeable pavers was based on these environmental factors:

1. Maximize the ability of every surface to slow, cool, cleanse, and infiltrate rainwater.

2. To demonstrate high-performance sustainable green infrastructure methods that could be applied elsewhere within the village of Glenview.

3. To add to the take-home lessons about the critical nature of urban hydrology and high quality, biodiverse natural landscapes. While the project did not need the stormwater storage per se, the design approach was to do everything possible to provide a completely stable, healthy hydrology for the expanded restored wetlands. 


\section{Educational programming (additional detail):}

The interpretive center also provides a variety of educational classes, which cost $\$ 5.25$ per student. Schools may select from a variety of topics, depending on the interest and age of the students. Class topics include:

- Prairie Primer: A guided walk along the prairie trails that will introduce students to the variety of native plants that grow on the prairie. Grade level: pre K-1

- Prairie 101: A class that focuses on what makes the prairie ecosystem and its native plants unique. It also includes discussions about fire, prairie wildlife, and natural history. Grade level: 1-6

- Recycling 101: An introduction to the importance of recycling and what happens to garbage when you throw it away, including how long items last in a landfill. Grade level: 3-5

- Weather Wise: An introduction into weather, how it affects our lives, and how to take measurements and readings from the interpretive center's weather station. Grade level: 3-5

- A Mighty Wind: An introduction to wind power and other alternative sources of energy. Includes the construction of a kite that the students will use to interact with the wind outside. Grade level: 5-8

- Scientific Methods: A hands-on science based class that provides students the opportunity to investigate the prairie and use different sampling methods. Grade level: 5-8

- Going Green: An introduction to the advanced design features of the LEED Platinum certified interpretive center building. Grade level: 6-8

- Human Footprint: A hands-on activity that teaches students about man's impact on the natural environment and how to calculate their carbon footprint. Grade level: 6-8 


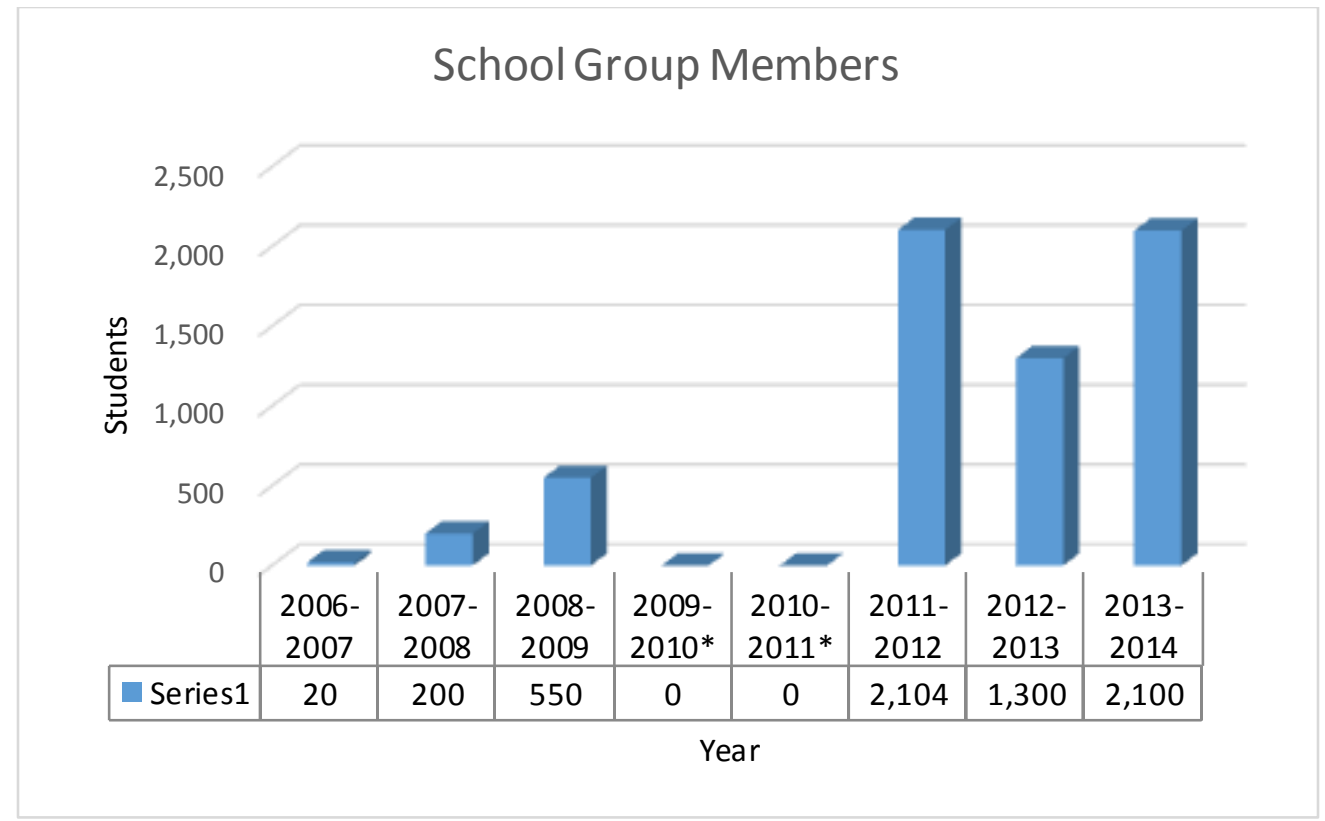

*Data for the 2009-2010 and 2010-2011 periods was not available.

The chart above shows just over a seven-fold increase in the numbers of school group visitors between the first three years of the Interpretive Center (2007-09) and the immediate past three years (2012-2014). Average student attendance 2011-2014:

$2,104+1,300+2,100=5,504$ students $/ 3$ years $=1,834.66$ students per year average

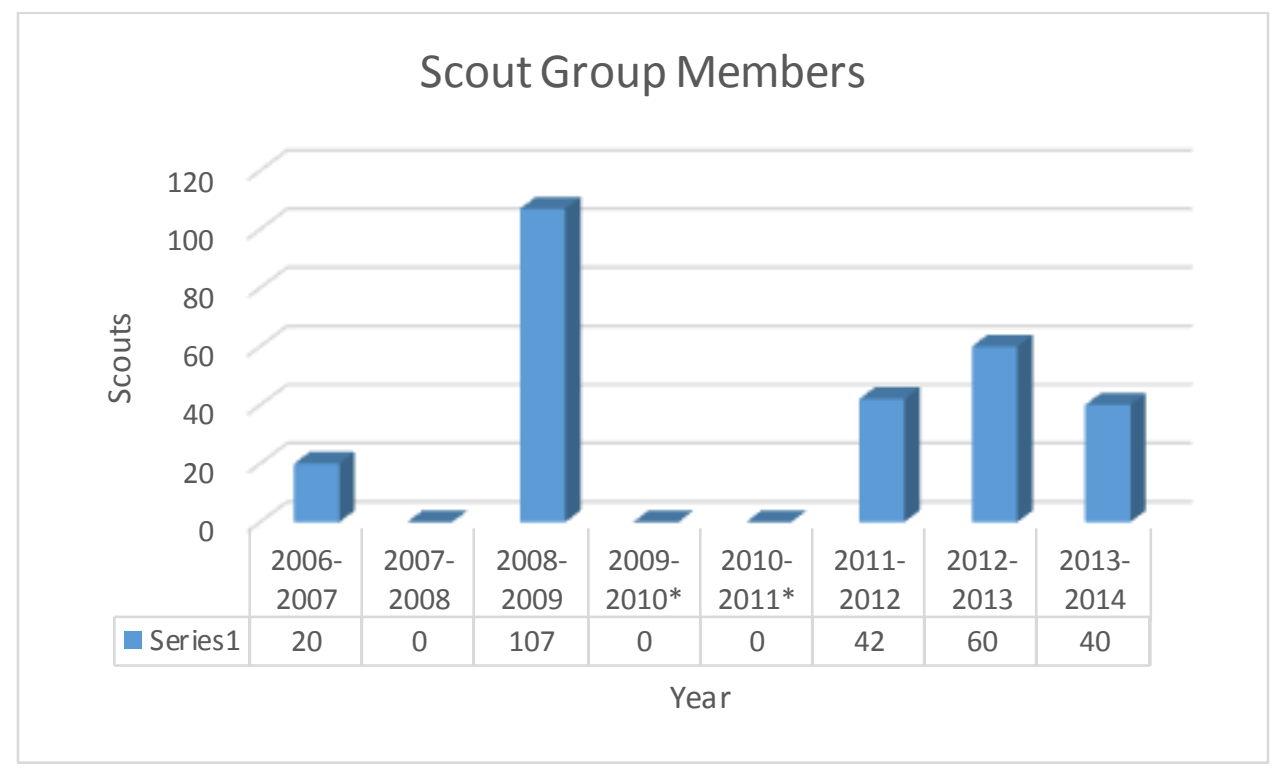

*Data for the 2009-2010 and 2010-2011 periods was not available.

Average scout attendance 2011-2014:

$42+60+40=142$ scouts $/ 3$ years $=47.33$ scouts per year average 
Sources:

- Attendance data provided by the Glenview Park District

- Course information from: http://www.glenviewparks.org/prev-uploads/MuseumSchool-Brochure-July2011.pdf

\section{Lessons Learned (additional detail):}

The prairie preservation project has encouraged the use of native plants in plantings on adjacent properties, signifying a potential increase in the public's awareness of the use of native plant species in the built environment.

While visiting the area surrounding the project site, the CSI team noticed that the native plant palette from the interpretive center has "overflowed" into the planting palette of some of the surrounding office parks. One property in particular, the site of the American College of Chest Physicians (CHEST), stood out as having heavily adopted the prairie aesthetic where their property backed up to the prairie.

In discussions with the CHEST project architect (Perkins+Will) and landscape architect (Daniel Weinbach \& Partners, Ltd), CSI team members were informed that although it was not the most important factor in selecting a location for the college, the site's adjacency to the prairie was a positive factor in the decision. Pedestrians are prevented from having direct access to the prairie by a berm running along the property line and by a dense layer of prairie grasses. However, the site design includes an exercise trail that does allow views to the prairie. 


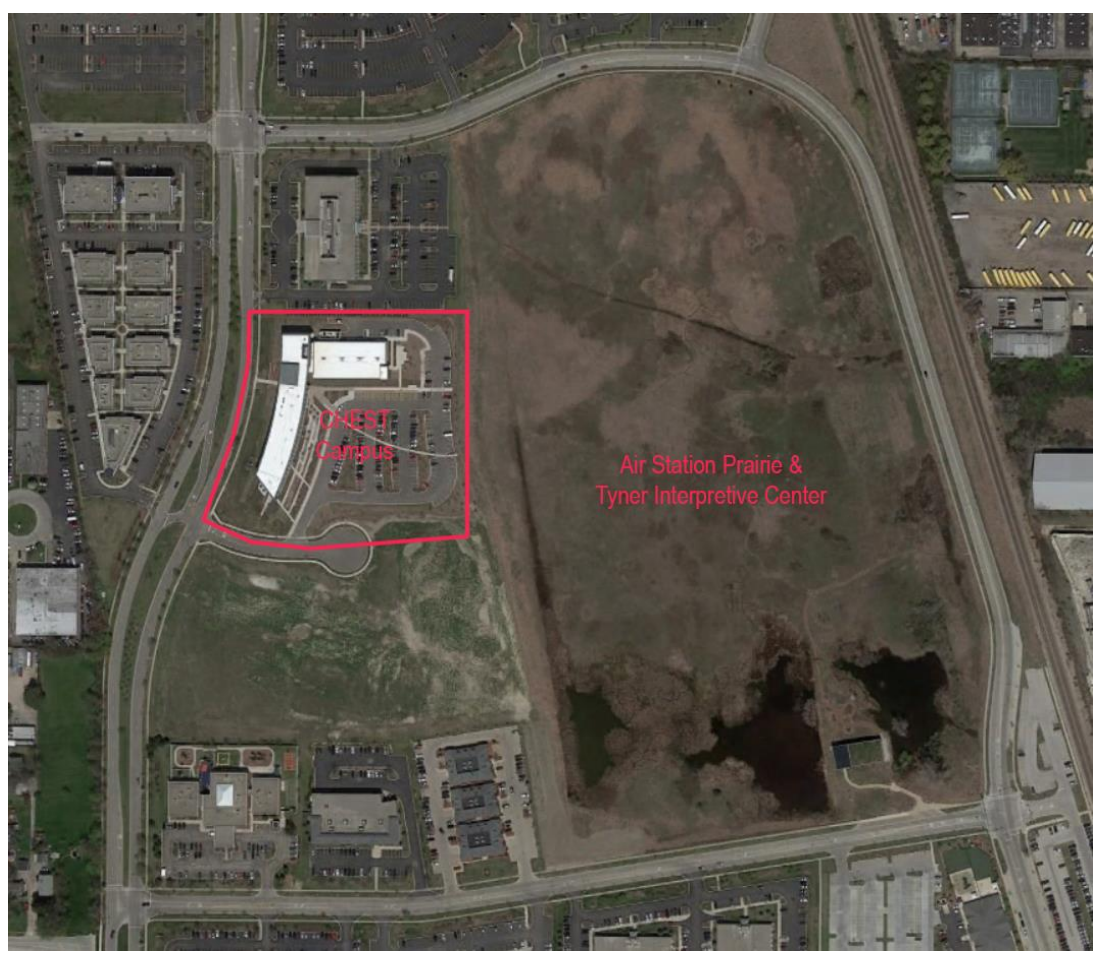

The American College of Chest Physicians campus is located directly adjacent to the prairie. Image from Google Earth.

The CHEST building was situated on the site so that they could capitalize on the views out over the prairie. The main office wing (where a majority of employees work) and a break room were oriented so their windows would have a view of the prairie. The landscaping on the site begins with a prairie-style aesthetic along the shared property line and the landscape design transitions into a more ordered, refined planting as it approaches the building. The project owner and the Village of Glenview were very supportive and complimentary of the overall design and integration of native plants into the project. At this point, however, the project landscape architect described the planting as being "too young" to be able to gauge any possible impacts on maintenance requirements.

Native plant areas on the perimeter of the site were seeded, while the areas closer to the building were planted as plugs. The plants and materials that have expanded beyond the bounds of the interpretive center include:

Grasses: Little Blue Stem (Andropogon scoparius), Prairie Cord Grass (Spartina 
pectinate)

Flowering perennials: New England Aster (Aster novae angliae), Heath Aster (Aster ericoides), Prairie Coreopsis (Coreopsis palmate), Pale Purple Coneflower (Echinacea pallida), Rough Blazing Star (Liatris aspera), Wild Bergamot (Monarda fistulosa), Foxglove Beard Tongue (Penstemon digitalis), Purple prairie clover (Petalostemum purpureum), Obedient Plant (Physostegia virginiana), Black-Eyed Susan (Rudbeckia hirta), Early Goldenrod (Solidago juncea), and Common Spiderwort (Tradescantia ohiensis)

Additional native trees and shrubs utilized on the site include: Sugar Maple (Acer saccharum), Kentucky Coffeetree (Gymnocladus dioica), Swamp White Oak (Quercus bicolor), Red Oak (Quercus rubra), River Birch (Betula Nigra), American Hazelnut (Corylus Americana), Chokeberry (Aronia Melanocarpa 'Autumn Magic'), Prairie Dropseed (Sporobolus Heterolepis)

Sources:

- Email correspondence with representatives from Perkins+Will and Daniel Weinbach \& Partners, LTD.

- Plant list provided by Daniel Weinbach \& Partners, LTD.

\section{Parking design (additional detail):}

While the Glenview zoning code required 8 parking spaces for the interpretive center, the designers and prairie advocates addressed concerns regarding the environmental impacts of parking on the ecosystem. The proximate availability of plentiful parking at the adjacent Metra train station commuter parking lot resulted in a successful bid for a variance to reduce the code-required parking for the site. The reduced number of parking spaces were incorporated into a compact $210 \mathrm{ft} \times 10 \mathrm{ft}(2,100 \mathrm{sf})$ curbed parking and pull-off area that is adjacent to, and running parallel with, Compass Road. The variant parking area provided space for 2 accessible parking spaces, 3 standard parking spaces and a bus pull-off/loading area. 


\section{Evelyn Pease Tyner Interpretive Center}

Methodology Page $\mathbf{2 3}$ of $\mathbf{2 3}$ 